\title{
Koyun ve inek sütlerinden üretilen Şanlıurfa Sadeyağlarının fiziksel, kimyasal ve mikrobiyolojik özelliklerinin belirlenmesi
}

\section{Determination of physical, chemical and microbiological properties of Şanlıurfa Sadeyağı produced from ovine and bovine milk}

\author{
Dilek YOKUŞ $^{1}$ iD Mehmet Şükrü KARAKUŞ $^{1}$ iD Ahmet Ferit ATASOY $^{1^{*}}$ iD \\ ${ }^{1}$ Harran Üniversitesi Mühendislik Fakültesi Gıda Mühendisliği Bölümü, Şanlıurfa/TÜRKiYE
}

To cite this article:

Yokuş, D., Karakuş, M.Ş. \& Atasoy, A.F. (2019). Koyun ve inek sütlerinden üretilen Şanlıurfa Sadeyağlarının fiziksel, kimyasal ve mikrobiyolojik özelliklerinin belirlenmesi. Harran Tarım ve Gıda Bilimleri Dergisi, 23(4): 463-476.

DOI: $10.29050 /$ harranziraat.538220

Address for Correspondence: Ahmet Ferit ATASOY e-mail:

fatasoy@harran.edu.tr

Received Date: 11.03.2019 Accepted Date: 21.06.2019

(C) Copyright 2018 by Harran University Faculty of Agriculture. Available on-line at www.dergipark.gov.tr/harranziraat

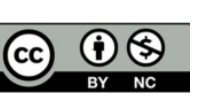
$\begin{aligned} & \text { This work is licensed } \\ & \text { under a } \\ & \text { Creative }\end{aligned}$
Non Commercial 4.0 öz

Bu çalışmada, 15 adet koyun ve 15 adet inek sütü kullanılarak üretilen Şanlıurfa Sadeyağlarının bazı fiziksel, kimyasal ve mikrobiyolojik özellikleri ile indüksiyon periyodu belirlenmiştir. Koyun ve inek Şanlıurfa Sadeyağlarına ait $L^{*}$ değeri 71.23-90.70, 75.01-85.14; a* değeri -1.90 ve $3.57,1.71-8.74 ; b^{*}$ değeri 10.21-19.70, 24.30-44.43 ve kırılma indisi değeri 1.456-1.462, 1.4251.462 arasında bulunmuştur. Koyun ve inek Şanlıurfa Sadeyağlarının yağ oranı \%98.00-99.25, \%95.00-99.00; yağsız kuru madde oranı \%0.17-1.94, \%0.31-4.71 (w/w); tuz miktarı \%0.00-0.05, \%0.00-0.03; titrasyon asitliği \%0.02-0.05, \%0.03-0.17 (L.A.); serbest asitlik 0.050-1.451, 0.520$8.208 \mathrm{mg} \mathrm{KOH} \mathrm{g}{ }^{-1}$ yağ; peroksit sayısı $0.122-0.338,0.012-0.385$ meq $\mathrm{O}_{2} \mathrm{~kg}^{-1}$ yağ; iyot sayısı 10.75-43.45, 2.51-50.25; sabunlaşma sayısı 251.02-306.02, 200.63-246.42 mg KOH g ${ }^{-1}$ yağ olarak belirlenmiştir. Koyun ve inek Şanlıurfa Sadeyağlarında yapılan mikrobiyolojik analizlerde lipolitik bakteri sayısı 0.84-3.69, 1.00-4.87 log kob g ${ }^{-1}$; maya-küf <1-5.06, 1.88-4.74 log kob g ${ }^{-1}$; laktik asit bakteri (M-17 ve MRS) sayıları 0.27-4.74, 0-4.61 log kob g ${ }^{-1} ; 0.70-5.25,<1-4.60$ log $\mathrm{kob} \mathrm{g}^{-1}$ ve indüksiyon periyodu değeri 0.23-13.64, 0.05-14.15 saat arasında değişmiştir. Koyun sadeyağlarının $L^{*}$ değeri $(p<0.05)$, yağ oranı $(p<0.01)$, peroksit sayısı $(p<0.01)$ ve sabunlaşma sayısı ( $p<0.001)$, inek sadeyağlarından yüksek; $a^{*}$ değeri $(p<0.001), b *$ değeri $(p<0.001)$, yağsız kurumadde miktarı $(p<0.01)$, titrasyon asitliği $(p<0.001)$, serbest asitlik değeri $(p<0.001)$ ve maya-küf sayısı $(p<0.001)$ inek Şanlıurfa Sadeyağlarından düşük olduğu tespit edilmiştir. Koyun ve inek sadeyağı örneklerinin kırılma indisi, tuz oranı, iyot sayısı, lipolitik bakteri sayısı, laktik asit bakteri sayısı ve indüksiyon periyodu değerleri arasında ( $p>0.005)$ fark bulunmamıştır. Bu sonuçlara göre, Şanlıurfa Sadeyağının standart bir üretim metodunun ve kalite kriterlerinin oluşturulmadığı belirlenmiştir.

Anahtar Kelimeler: Şanlıurfa Sadeyağı, kimyasal özellikler, mikrobiyolojik özellikler, indüksiyon periyodu

\section{ABSTRACT}

In this study, some physical, chemical, microbiological properties and induction period of Şanlıurfa Sadeyağı produced from ovine and bovine was determined. $L^{*}, a^{*}, b^{*}$ values and refractive index of ovine and bovine Şanlıurfa Sadeyağı were found between 71.23-90.70, 75.01-85.14; -1.90 and -3.57, 1.71-8.74; 10.21-19.70,24.30-44.43 and 1.456-1.462, 1.4251.462 , respectively. Fat content, non-fat dry matter, salt content, titratable acidity, free acidity, peroxide number, iodine number and saponification number of ovine and bovine Şanlıurfa Sadeyağı were determined as $98-99.25 \%, 95-99 \%(w / w) ; 0.17-1.94 \%, 0.31-4.71 \%$ $(w / w) ; 0.00-0.05 \%, 0.00-0.03 \%$ (w/w); 0.02-0.05\%, 0.03-0.17\% (L.A.); 0.050-1.451, 0.520-8.208 $\mathrm{mg} \mathrm{KOH} \mathrm{g}^{-1}$ fat; $0.122-0.338,0.012-0.385$ meq $\mathrm{O}_{2} \mathrm{~kg}^{-1}$ fat; $10.75-43.45,2.51-50.25$ and 251.02$306.02,200.63-246.42 \mathrm{mg} \mathrm{KOH} \mathrm{g}^{-1}$ fat, respectively. Lipolytic bacteria, yeast-mold, lactic acid bacteria (M-17 and MRS) counts of ovine and bovine Şanlıurfa Sadeyağı were determined as 0.84-3.69, 1.00-4.87 log cfu g ${ }^{-1} ;<1-5.06,1.88-4.74 \log \mathrm{cfu} \mathrm{g}^{-1} ; 0.27-4.74,<1-4.61$ log cfu g $0.70-5.25,0-4.60 \log _{\text {cfu g }}{ }^{-1}$, respectively. Induction period value of ovine and bovine Şanlıurfa Sadeyağı was $0.23-13.64,0.05-14.15$ hour, respectively. $L^{*}$ value $(p<0.05)$, fat content 
$(p<0.01)$, peroxide number $(p<0.01)$ and saponification number $(p<0.001)$ of ovine sadeyağı was found higher than bovine sadeyağı. $a^{*}$ value $(p<0.001), b^{*}$ value $(p<0.001)$, non-fat dry matter $(p<0.01)$, titratable acidity $(p<0.001)$, free acidity value $(p<0.001)$ and yeast-mold count $(p<0.001)$ of ovine sadeyağı was found lower than bovine sadeyağı. No difference was found between refractive index, salt content, iodine number, count of lipolytic bacteria, count of lactic acid bacteria and induction period values ( $p>0.005$ ) of ovine and bovine Şanlıurfa Sadeyağı samples. According to these results, it was determined that a standard production method and quality criteria of the Şanlıurfa Sadeyağı was not established.

Key Words: Şanlıurfa Sadeyağı, chemical properties, microbiological properties, induction period

\section{Giriş}

Sadeyağ; süt ve/veya süt ürünlerinden elde edilen, su ve yağsız kurumadde unsurlarının tamamına yakın bölümü uzaklaştırılmış ağırlıkça en az \%99 oranında süt yağı içeriğine sahip ürün olarak tanımlanmaktadır (Anonim, 2005). Şanlıurfa Sadeyağı (Urfa Yağı), endemik bitkilerin yoğun olduğu (Tek Tek platosu, Fatik platosu, Karacadağ vd) bölgelerde beslenen bölgeye özgü ivesi koyun sütünden üretilen yoğurdun yayıklanması sonucu elde edilen tereyağlarının eritilmesiyle elde edilmektedir (Atasoy ve Türkoğlu, 2010).

Türkiye'de hemen hemen her bölgede sadeyağ üretimi yapılmaktadır. Ancak, birçok yörede tüketicilerin kendileri için üretmeleri nedeniyle Doğu ve Güneydoğu Anadolu bölgesi haricinde ticari bir değer kazanmamıştır. Ticari değeri olan sadeyağ ise ülkemizde çoğunlukla büyükbaş hayvan (inek) sütünden üretilmekle birlikte, bazı bölgelerde küçükbaş hayvanların (koyun, keçi veya karışımlarından) sütünden üretilmektedir. Şanlıurfa Sadeyağı yörede geleneksel yöntemlerle üretilmektedir. Bu yönteme göre; sağılan sütler kaba kirlerinden tülbent yardımıyla süzülür. Süzülen sütler daha sonra uygun bir kap içerisinde yoğurda işlemek amacıyla kaynatılır. Mayalama sıcaklığına soğutulan sütler mayalanarak yoğurt üretilir. Üretilen yoğurtlar bir gece buzdolabında bekletilerek tat aroma gelişimi tamamlanır. Ertesi gün eşit miktarda yoğurt ve su karışımı "yayık", "tuluk" adı verilen tahtadan veya hayvan derisinden yapılan kaplara ya da son zamanlarda olduğu gibi yayıklama makinesine konularak yayıklanır. Yayıklama aşamasında karışımın sıcaklığı tereyağı oluşumuna (kristalizasyon) izin verecek derecede olmalıdır. Bu amaçla havaların sıcak olması durumunda su yerine buz kullanılır.
Yayıklama sonrası oluşan yayık altı (ayran) uzaklaştırıldıktan sonra oluşan tereyağları temiz su yardımıyla yıkanarak buzdolabına alınır. Bu şekilde yaklaşık 7-10 gün kadar tereyağı üretilir. Üretilen tereyağları $100{ }^{\circ} \mathrm{C}^{\prime}$ nin altındaki sıcaklıkta eritilerek su ve yağsız kurumadde bileşenlerinin (köpük) uzaklaşması sağlanarak sadeyağ üretimi tamamlanır.

Şanlıurfa Sadeyağına benzer ürünler özellikle Orta Doğu, Asya ve Afrika'da üretilmektedir. Bu ürün Hindistan'da “Ghee"', Orta Doğu'da "Maslee" veya 'Samn" , İran'da ise "Roghan" olarak isimlendirilmektedir (Atasoy ve Türkoğlu, 2010). Ancak dünya genelinde Hindistan'daki ismiyle bilinmektedir. Bu nedenle bu ürün uluslararası literatürde "ghee", "clarified butter oil", "butter oil" olarak adlandırılmaktadır.

Şanlıurfa Sadeyağı, koyun sütünden üretilmesine rağmen, son yıllarda bölgede sulu tarıma geçilmesiyle meraların ve küçükbaş hayvan sayısının azalması sonucu üretimin tüketimi karşılamaması ve koyun sadeyağının fiyatının yüksek olması gibi nedenlerden dolayı inek sütünden de Şanlıurfa Sadeyağı üretilmektedir. Ayrıca koyun sadeyağına inek sadeyağı karıştırılarak, taklit ve tağşişlerin yapılarak piyasaya sunulması sadeyağ ticareti ile uğraşanlar arasında haksız rekabete ve tüketicilerin mağdur olmasına neden olmaktadır. İlave olarak Şanlıurfa Sadeyağı kalite özellikleriyle ilgili herhangi bir çalışma bulunmamaktadır. $\mathrm{Bu}$ nedenlerle bu çalışmada, koyun ve inek Şanlıurfa Sadeyağlarının fiziksel, kimyasal ve mikrobiyolojik özellikleri ile indüksiyon periyodunun saptanması ve piyasaya arz edilen örnekler arasındaki farkların belirlenmesi amaçlanmıştır. 


\section{Materyal ve Metot}

Bu araştırmada, 2016 yılı ilkbahar döneminde, Şanlıurfa yöresinde geleneksel yöntemlerle üretilen 15 adet koyun ve 15 adet inek Şanlıurfa Sadeyağı örneği piyasadan alınarak incelenmiştir. Sadeyağ örnekleri önceden sterilize edilmiş kavanozlara alınarak hemen laboratuvara getirilmiş ve analize alınmıştır. Sadeyağların üretildiği yerler Çizelge 1'de gösterilmiştir.

Çizelge 1. Koyun ve inek Şanlıurfa Sadeyağlarının temin edildiği yerler

Table 1. Locations of ovine and bovine Şanlıurfa Sadeyağı

\begin{tabular}{|c|c|c|c|c|}
\hline $\begin{array}{c}\text { Örnek } \\
\text { Sample }\end{array}$ & $\begin{array}{c}\text { Türü } \\
\text { Species }\end{array}$ & $\begin{array}{c}\text { Alındığı yer } \\
\text { Location }\end{array}$ & $\begin{array}{c}\text { Türü } \\
\text { Species }\end{array}$ & $\begin{array}{c}\text { Alındığı yer } \\
\text { Location }\end{array}$ \\
\hline 1 & Koyun & Merkez & İnek & Ceylanpınar \\
\hline 2 & Koyun & Merkez & İnek & Viranşehir \\
\hline 3 & Koyun & Merkez & İnek & $*$ \\
\hline 4 & Koyun & Merkez & İnek & $*$ \\
\hline 5 & Koyun & Viranşehir & İnek & Ulugerger \\
\hline 6 & Koyun & Birecik & İnek & $*$ \\
\hline 7 & Koyun & Hilvan & İnek & $*$ \\
\hline 8 & Koyun & Hilvan & Inek & $*$ \\
\hline 9 & Koyun & Hilvan & Innek & Ulugerger \\
\hline 10 & Koyun & Siverek & İnek & Merkez \\
\hline 11 & Koyun & Siverek & İnek & Merkez \\
\hline 12 & Koyun & Siverek & İnek & Harran \\
\hline 13 & Koyun & Siverek & İnek & Harran \\
\hline 14 & Koyun & Viranşehir & İnek & Harran \\
\hline 15 & Koyun & Ceylanpınar & İnek & Siverek \\
\hline
\end{tabular}

* ile belirtilen örneklerin orijinleri bilinmemektedir.

\section{Fiziksel analizler}

Renk tayini analizi Hunter Lab cihazı (Colour Quest XE, UK), kırılma indisi tayini Abbe Refraktometresi kullanılarak yapılmıştır.

\section{Kimyasal analizler}

Örneklerde yağ, yağsız kurumadde, tuz, titrasyon asitliği, serbest asitlik ve peroksit tayini British Standard 684 (1987), iyot değeri AOAC (1990), sabunlaşma sayısı Egan ve ark. (1981) tarafından verilen yöntemlere göre belirlenmiştir.

\section{Mikrobiyolojik Analizler}

Lipolitik mikroorganizma sayısı Frank ve Yousef (2004), maya-küf ve laktik asit bakteri sayısı Halkman (2005)'a göre yapılmıştır.

Indüksiyon periyodu tayini

Indüksiyon periyodu tayini Rancimat cihazı (892 Professional Rancimat) kullanılarak belirlenmiştir.

\section{Istatistiksel Analizler}

İstatistiksel analizler; SPSS 9.0 paket programı kullanılarak gerçekleştirilmiş ve tek yönlü varyans analiz (ANOVA) metodu kullanılmıştır.

\section{Araştırma Bulguları ve Tartışma}

\section{Fiziksel özellikler}

Şanlıurfa Sadeyağı örneklerinin bazı fiziksel özellikleri Çizelge 2 'de verilmiş, örneklere ait ortalama $L^{*}, a^{*}, b^{*}$ ve kırılma indisi değerleri ise Şekil $1^{\prime}$ de gösterilmiştir.
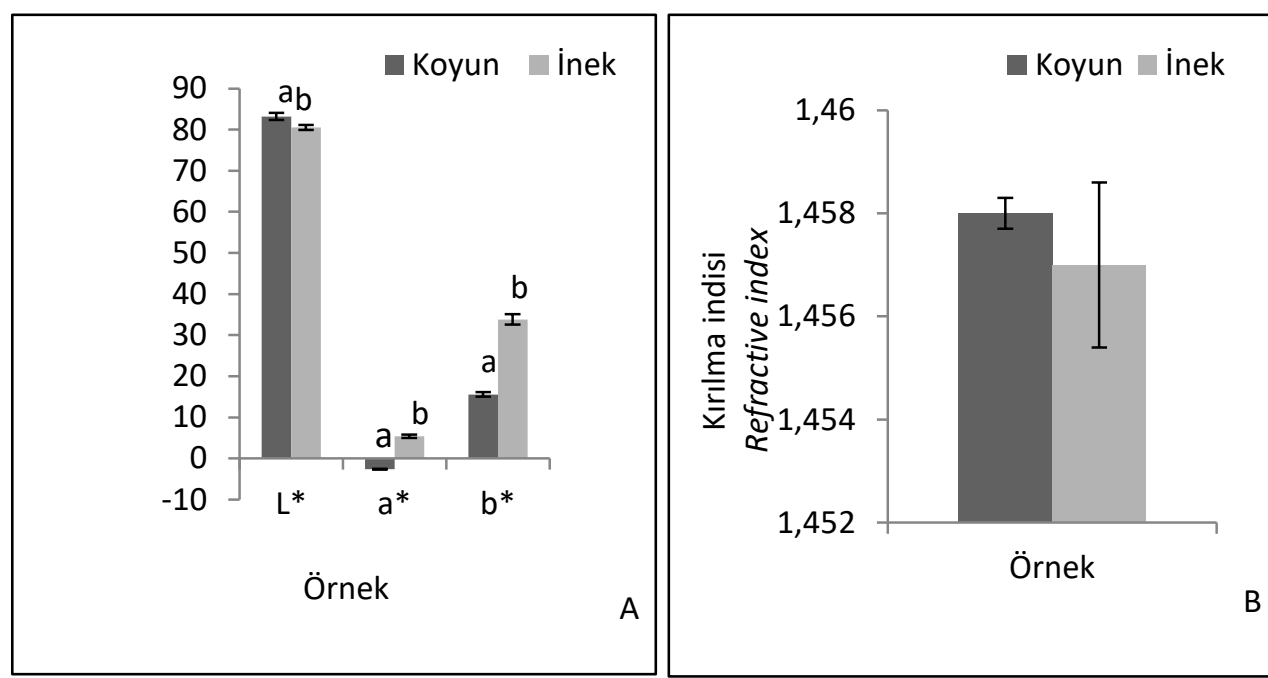

Şekil 1. Koyun ve inek Şanlıurfa Sadeyağlarının fiziksel özelliklerinin ortalama değerleri (A: $L^{*}, a^{*}, b^{*}$ renk analizi ortalamaları; B: Kırılma indisi ortalaması)

Figure 1. Mean values of physical properties of ovine and bovine Şanlıurfa Sadeyağı (A: Mean value of $L *, a *, b *$ color analysis; $B$ : Mean value of refraction index) 
Çizelge 2. Koyun ve inek Şanlıurfa Sadeyağı örneklerine ait bazı fiziksel özellikler Table 2. Some physical properties of ovine and bovine Şanlıurfa Sadeyağı samples

\begin{tabular}{|c|c|c|c|c|c|c|c|c|}
\hline \multirow[t]{2}{*}{$\begin{array}{l}\text { Örnek } \\
\text { Sample }\end{array}$} & \multicolumn{2}{|c|}{$L^{*}$} & \multicolumn{2}{|c|}{$a^{*}$} & \multicolumn{2}{|c|}{$b^{*}$} & \multicolumn{2}{|c|}{$\begin{array}{c}\text { Kırılma indisi } \\
\text { Refractive index }\end{array}$} \\
\hline & Koyun & İnek & Koyun & İnek & Koyun & İnek & Koyun & İnek \\
\hline 1 & $78.00 \pm 0.55^{b}$ & $77.13 \pm 0.18^{b}$ & $-2.88 \pm 0.04^{c}$ & $8.74 \pm 0.06^{\prime}$ & $19.52 \pm 0.04$ & $43.09 \pm 0.06^{m}$ & $1.458 \pm 0.00^{\mathrm{bcd}}$ & $1.459 \pm 0.00^{\text {cd }}$ \\
\hline 2 & $79.80 \pm 0.22^{c}$ & $78.50 \pm 0.14^{c}$ & $-2.58 \pm 0.02^{\mathrm{g}}$ & $8.29 \pm 0.06^{k}$ & $14.19 \pm 0.06^{e}$ & $41.61 \pm 0.05^{k}$ & $1.457 \pm 0.00^{\mathrm{abc}}$ & $1.458 \pm 0.00^{\text {cd }}$ \\
\hline 3 & $85.62 \pm 0.55^{\mathrm{fg}}$ & $78.48 \pm 0.16^{c}$ & $-2.75 \pm 0.03^{\mathrm{de}}$ & $3.91 \pm 0.02^{\mathrm{e}}$ & $15.73 \pm 0.01^{g}$ & $27.10 \pm 0.05^{d}$ & $1.457 \pm 0.00^{\mathrm{ab}}$ & $1.462 \pm 0.00^{\mathrm{e}}$ \\
\hline 4 & $83.10 \pm 0.15^{\mathrm{d}}$ & $75.01 \pm 0.36^{a}$ & $-2.67 \pm 0.02^{\mathrm{efg}}$ & $7.70 \pm 0.06^{j}$ & $19.70 \pm 0.04^{m}$ & $44.43 \pm 0.02^{n}$ & $1.458 \pm 0.00^{\mathrm{cd}}$ & $1.458 \pm 0.00^{\text {cd }}$ \\
\hline 5 & $85.52 \pm 0.14^{\mathrm{fg}}$ & $85.14 \pm 0.50^{g}$ & $-3.20 \pm 0.06^{b}$ & $5.79 \pm 0.17^{g}$ & $10.99 \pm 0.06^{b}$ & $33.50 \pm 0.06^{g}$ & $1.459 \pm 0.00^{d}$ & $1.458 \pm 0.00^{\text {cd }}$ \\
\hline 6 & $87.95 \pm 0.30^{h}$ & $78.81 \pm 0.42^{c}$ & $-2.73 \pm 0.04^{\text {def }}$ & $6.58 \pm 0.04^{h}$ & $11.29 \pm 0.03^{c}$ & $38.55 \pm 0.08^{i}$ & $1.457 \pm 0.00^{\mathrm{abc}}$ & $1.458 \pm 0.00^{\text {cd }}$ \\
\hline 7 & $84.76 \pm 0.47^{\mathrm{efg}}$ & $84.36 \pm 0.13^{g}$ & $-2.18 \pm 0.02^{i}$ & $2.46 \pm 0.03^{b}$ & $19.42 \pm 0.03^{1}$ & $25.40 \pm 0.03^{b}$ & $1.457 \pm 0.00^{\mathrm{abc}}$ & $1.458 \pm 0.00^{\mathrm{bc}}$ \\
\hline 8 & $85.95 \pm 0.38^{g}$ & $80.08 \pm 0.28^{d}$ & $-2.32 \pm 0.06^{h}$ & $8.31 \pm 0.02^{k}$ & $15.21 \pm 0.03^{f}$ & $42.45 \pm 0.08^{\prime}$ & $1.457 \pm 0.00^{\mathrm{ab}}$ & $1.458 \pm 0.00^{\text {cd }}$ \\
\hline 9 & $71.23 \pm 0.03^{\mathrm{a}}$ & $84.68 \pm 0.55^{g}$ & $-2.67 \pm 0.04^{\mathrm{efg}}$ & $2.81 \pm 0.03^{c}$ & $17.72 \pm 0.03^{j}$ & $26.95 \pm 0.11^{d}$ & $1.458 \pm 0.00^{\mathrm{bcd}}$ & $1.462 \pm 0.00^{\mathrm{e}}$ \\
\hline 10 & $77.08 \pm 0.06^{b}$ & $81.98 \pm 0.24^{\mathrm{e}}$ & $-2.19 \pm 0.03^{i}$ & $3.74 \pm 0.02^{d}$ & $13.47 \pm 0.05^{\mathrm{d}}$ & $28.42 \pm 0.03^{\mathrm{e}}$ & $1.457 \pm 0.00^{\mathrm{abc}}$ & $1.425 \pm 0.00^{\mathrm{a}}$ \\
\hline 11 & $84.70 \pm 0.60^{\mathrm{efg}}$ & $77.80 \pm 0.45^{\mathrm{bc}}$ & $-2.83 \pm 0.04^{\text {cd }}$ & $3.69 \pm 0.03^{d}$ & $17.41 \pm 0.02^{i}$ & $24.30 \pm 0.07^{a}$ & $1.456 \pm 0.00^{\mathrm{a}}$ & $1.456 \pm 0.00^{b}$ \\
\hline 12 & $85.15 \pm 0.02^{\mathrm{efg}}$ & $83.35 \pm 0.38^{f}$ & $-2.35 \pm 0.05^{h}$ & $1.71 \pm 0.02^{\mathrm{a}}$ & $18.06 \pm 0.08^{k}$ & $26.28 \pm 0.08^{c}$ & $1.462 \pm 0.00^{\mathrm{e}}$ & $1.462 \pm 0.00^{\mathrm{e}}$ \\
\hline 13 & $90.70 \pm 0.53^{i}$ & $84.55 \pm 0.30^{g}$ & $-1.90 \pm 0.06^{j}$ & $5.78 \pm 0.04^{\mathrm{g}}$ & $10.21 \pm 0.05^{\mathrm{a}}$ & $34.52 \pm 0.10^{h}$ & $1.458 \pm 0.00^{\mathrm{bcd}}$ & $1.460 \pm 0.00^{d}$ \\
\hline 14 & $84.18 \pm 1.14^{\mathrm{def}}$ & $75.27 \pm 0.03^{\mathrm{a}}$ & $-2.61 \pm 0.04^{f g}$ & $6.75 \pm 0.02^{i}$ & $14.20 \pm 0.04^{e}$ & $39.54 \pm 0.09^{j}$ & $1.458 \pm 0.00^{\mathrm{cd}}$ & $1.458 \pm 0.00^{\text {cd }}$ \\
\hline 15 & $83.78 \pm 0.43^{\mathrm{de}}$ & $82.62 \pm 0.39^{\text {ef }}$ & $-3.57 \pm 0.05^{\mathrm{a}}$ & $4.57 \pm 0.02^{f}$ & $16.63 \pm 0.03^{h}$ & $31.31 \pm 0.14^{\dagger}$ & $1.457 \pm 0.00^{\mathrm{abc}}$ & $1.458 \pm 0.00^{\mathrm{bc}}$ \\
\hline
\end{tabular}


Koyun Şanlıurfa Sadeyağlarının $L^{*}$ değeri 71.23-90.70, inek sadeyağlarının ise 75.01-85.14 arasında değiştiği tespit edilmiştir. Örneklerin L* değerlerinin istatistiksel olarak birbirlerinden farklı olduğu saptanmıştır $(p<0.05)$. Bu farklılığın hayvan ırkı, beslenme şekli, yem ve sütün kalitesi gibi faktörlerden kaynaklandığı düşünülmektedir. Koyun Şanlıurfa Sadeyağının ortalama $L^{*}$ değerinin, inek sadeyağından yüksek olduğu bulunmuştur $(p<0.05)$ (Şekil 1A). Bu durum koyun sadeyağının, inek sadeyağından daha beyaz ve parlak olduğunu göstermektedir.

a* değeri koyun sadeyağlarında minimum 3,57, maksimum -1.90, inek sadeyağlarında ise minimum 1.71, maksimum 8.74 olduğu belirlenmiştir. Ayrıca, koyun Şanlıurfa Sadeyağlarının ortalama $a^{*}$ değerinin -2.63 , inek sadeyağlarının ise 5,39 olduğu belirlenmiştir. Koyun ve inek Şanlıurfa Sadeyağlarının ortalama a* değerleri arasındaki fark istatistiksel olarak çok önemli bulunmuştur ( $p<0.001$ ) (Şekil 1A).

Koyun Şanlıurfa Sadeyağı örneklerinin $b^{*}$ değerleri 10.21-19.70, inek sadeyağı örneklerinin b* değerleri ise 24.30-44.43 arasında olduğu belirlenmiştir. Örneklerin $b^{*}$ değerinin istatistiksel olarak birbirlerinden farklı olduğu tespit edilmiştir $(p<0.05)$. İnek sadeyağının ortalama $b^{*}$ değerinin, koyun sadeyağından daha yüksek olduğu bulunmuştur $(p<0.001)$ (Şekil 1A). Bu sonuç, inek sadeyağlarının sarımtırak, koyun sadeyağlarının ise beyazımtırak olduğunu göstermektedir. $\mathrm{Bu}$ durumun özellikle inek sütünde $A$ vitamini ve $\beta$ karoten bulunmasından ve beslenme şeklinden kaynaklandığı Tahmas Kahyaoğlu ve Çakmakçı (2018) tarafından da belirtilmiştir. Aynı araştırıcılar koyun ve inek sütünden elde edilen tereyağlarında ortalama $b^{*}$ değerini sırasıyla 10.90 ve 19.21 olduğunu belirlemiştir. Bu sonuç çalışmada elde edilen sonuçlarla paralellik göstermektedir.

Koyun Şanlıurfa Sadeyağı örneklerinin kırılma indisi değerleri 1.456-1.462, inek Şanlıurfa Sadeyağlarında ise 1.425-1.462 arasında değiştiği saptanmıştır. Örneklerin kırılma indisi değerlerinin istatistiksel olarak birbirlerinden farklı $(p<0.05)$ olduğu bulunmuştur. Ancak inek ve koyun Şanlıurfa Sadeyağlarının ortalama kırılma indisi değerleri arasında istatistiksel olarak bir fark bulunmamıştır $(p>0.05) \quad$ (Şekil 1B). TS 1331 Tereyağı Standardında kırılma indisi 1.452-1.462 arasında olması gerektiği belirtilmiştir (Anonim, 1995). Koyun ve inek Şanlıurfa Sadeyağı örnekleri genel olarak bu aralıkta bulunurken, birer tanesi bu aralığın dışında kalmaktadır.

\section{Kimyasal Özellikler}

Koyun ve inek sadeyağı örneklerinin bazı kimyasal özellikleri Çizelge 3'te verilmiş, ortalama değerleri ise Şekil 2'de gösterilmiştir.

Koyun ve inek Şanlıurfa Sadeyağı örneklerinin yağ ve yağsız kurumadde oranları sırasıyla \%98.00-99.25 (w/w) ve \%0.17-1.94 (w/w); \%95-99 $(w / w)$ ve \%0.31-4.71 (w/w) arasında olduğu tespit edilmiştir. Örneklerin yağ ve yağsız kurumadde oranlarının istatistiksel olarak birbirlerinden farklı olduğu tespit edilmiştir $(p<0.05)$. Bu durumun, geleneksel yöntemlerle üretilen Şanlıurfa Sadeyağlarının üreticilerin farklılığına bağlı olarak su ve tortusunun farklı oranda uzaklaştırılması bu nedenle standardın sağlanamamasından kaynaklandığı tahmin edilmektedir. Ayrıca, koyun ve inek Şanlıurfa Sadeyağlarının ortalama yağ ve yağsız kurumadde miktarlarının istatistiksel olarak birbirinden farklı olduğu belirlenmiştir $(p<0.01)$ (Şekil 2A ve 2B). Türk Gıda Kodeksine göre sadeyağın ağırıkça en az \%99 oranında süt yağı içermesi gerekmektedir. Bu araştırmada koyun sadeyağ örneklerinden 9, inek sadeyağ örneklerinden ise 11 tanesi bu değerin altında yer almışlardır. Sadeyağ örneklerinin yağ miktarları üzerine yapılan çalışmalarda; Batun ve ark. (2004), \%93.85-99.40 (w/w), Findık (2011) \%99.07-99.89 $(w / w)$, Kirazcı ve Javidipour (2008) \%93.85-99.40 (w/w) arasında olduğunu belirtmişlerdir.

Örneklerin tuz miktarları koyun sadeyağı için $\% 0.00-0.05(\mathrm{w} / \mathrm{w})$, inek sadeyağı için ise \%0.00$0.03(\mathrm{w} / \mathrm{w})$ arasında değiştiği belirlenmiştir. Koyun ve inek sadeyağı örneklerinin ortalama tuz miktarları arasında istatistiksel olarak fark bulunmadığı belirlenmiştir ( $p>0.05)$. Bu durumun gerek bölgede, gerekse Türkiye'nin birçok yerinde sadeyağın başta baklava üreticileri olmak üzere, tatlı ürünlerinin üretilmesinde kullanılmasından kaynaklandığı düşünülmektedir. İlave olarak sadeyağın su ve yağsız kurumadde oranının çok düşük olması, antioksidan kapasitesinin yüksek olması nedeniyle tuz oranının düşük tutulduğu tahmin edilmektedir (Atasoy ve Türkoğlu, 2010). 
Çizelge 3. Koyun ve inek Şanlıurfa Sadeyağı örneklerine ait bazı kimyasal özellikler

Table 3. Some chemical properties of ovine and bovine Şanlıurfa Sadeyağı samples

\begin{tabular}{|c|c|c|c|c|c|c|c|c|}
\hline \multirow[t]{2}{*}{$\begin{array}{l}\text { Örnek } \\
\text { Sample }\end{array}$} & \multicolumn{2}{|c|}{$\begin{array}{l}\text { Yağ oranı (\%) } \\
\text { Fat content (\%) }\end{array}$} & \multicolumn{2}{|c|}{$\begin{array}{l}\text { Yağsız kurumadde (\%) } \\
\text { Non-fat dry matter (\%) }\end{array}$} & \multicolumn{2}{|c|}{$\begin{array}{c}\text { Tuz oranı (\%) } \\
\text { Salt content (\%) } \\
\end{array}$} & \multicolumn{2}{|c|}{$\begin{array}{l}\text { Titrasyon asitliği (\% laktik asit) } \\
\text { Titratable acidity (lactic acid \%) }\end{array}$} \\
\hline & Koyun & İnek & Koyun & Inek & Koyun & İnek & Koyun & İnek \\
\hline 1 & $99.25 \pm 0.25^{b}$ & $98.00 \pm 0.00^{b c}$ & $0.59 \pm 0.27^{\mathrm{a}}$ & $1.79 \pm 0.00^{c}$ & $0.01 \pm 0.00^{c}$ & $0.01 \pm 0.00^{c}$ & $0.04 \pm 0.01^{\mathrm{cd}}$ & $0.03 \pm 0.00^{\mathrm{a}}$ \\
\hline 2 & $98.00 \pm 0.00^{\mathrm{a}}$ & $98.50 \pm 0.50^{b c}$ & $1.25 \pm 0.62^{\mathrm{ab}}$ & $0.88 \pm 0.43^{\mathrm{abc}}$ & $0.01 \pm 0.00^{c}$ & $0.01 \pm 0.00^{d}$ & $0.03 \pm 0.01^{\mathrm{ab}}$ & $0.05 \pm 0.00^{c}$ \\
\hline 3 & $98.75 \pm 0.75^{\mathrm{ab}}$ & $99.00 \pm 0.00^{c}$ & $0.45 \pm 0.38^{\mathrm{a}}$ & $0.86 \pm 0.04^{\mathrm{abc}}$ & $0.02 \pm 0.00^{d}$ & $0.02 \pm 0.00^{j}$ & $0.02 \pm 0.00^{a}$ & $0.17 \pm 0.00^{i}$ \\
\hline 4 & $98.00 \pm 0.00^{\mathrm{a}}$ & $98.50 \pm 0.50^{b c}$ & $0.65 \pm 0.04^{\mathrm{a}}$ & $0.97 \pm 0.55^{a b c}$ & $0.01 \pm 0.00^{c}$ & $0.02 \pm 0.00^{k}$ & $0.03 \pm 0.01^{a b}$ & $0.06 \pm 0.01^{c d}$ \\
\hline 5 & $98.00 \pm 0.00^{\mathrm{a}}$ & $97.50 \pm 0.50^{b}$ & $1.94 \pm 0.03^{b}$ & $0.53 \pm 0.43^{\mathrm{ab}}$ & $0.01 \pm 0.01^{b}$ & $0.01 \pm 0.00^{\mathrm{e}}$ & $0.04 \pm 0.00^{\mathrm{de}}$ & $0.12 \pm 0.00^{f g}$ \\
\hline 6 & $99.25 \pm 0.25^{b}$ & $98.50 \pm 0.50^{b c}$ & $0.41 \pm 0.37^{\mathrm{a}}$ & $1.05 \pm 0.48^{\mathrm{abc}}$ & $0.00 \pm 0.00^{a}$ & $0.01 \pm 0.00^{f}$ & $0.05 \pm 0.01^{e}$ & $0.07 \pm 0.01^{\mathrm{de}}$ \\
\hline 7 & $98.00 \pm 0.00^{\mathrm{a}}$ & $98.00 \pm 0.00^{b c}$ & $0.71 \pm 0.57^{\mathrm{a}}$ & $1.73 \pm 0.02^{c}$ & $0.02 \pm 0.00^{d}$ & $0.01 \pm 0.00^{\mathrm{g}}$ & $0.02 \pm 0.00^{a}$ & $0.04 \pm 0.01^{\mathrm{ab}}$ \\
\hline 8 & $98.00 \pm 0.00^{a}$ & $98.50 \pm 0.50^{b c}$ & $0.17 \pm 0.00^{a}$ & $1.41 \pm 0.53^{b c}$ & $0.05 \pm 0.00^{e}$ & $0.00 \pm 0.00^{a}$ & $0.04 \pm 0.00^{\mathrm{de}}$ & $0.05 \pm 0.01^{b c}$ \\
\hline 9 & $98.75 \pm 0.75^{\mathrm{ab}}$ & $98.00 \pm 0.00^{b c}$ & $0.24 \pm 0.05^{\mathrm{a}}$ & $0.31 \pm 0.03^{\mathrm{a}}$ & $0.01 \pm 0.00^{c}$ & $0.01 \pm 0.00^{h}$ & $0.03 \pm 0.00^{b c}$ & $0.07 \pm 0.00^{e}$ \\
\hline 10 & $98.50 \pm 0.50^{\mathrm{ab}}$ & $95.00 \pm 0.00^{a}$ & $0.46 \pm 0.43^{\mathrm{a}}$ & $4.71 \pm 0.04^{d}$ & $0.01 \pm 0.00^{c}$ & $0.03 \pm 0.00^{m}$ & $0.02 \pm 0.00^{a}$ & $0.11 \pm 0.00^{f}$ \\
\hline 11 & $99.00 \pm 0.00^{\mathrm{ab}}$ & $95.00 \pm 0.00^{\mathrm{a}}$ & $0.78 \pm 0.21^{\mathrm{a}}$ & $4.42 \pm 0.07^{d}$ & $0.00 \pm 0.00^{a}$ & $0.02 \pm 0.00$ & $0.03 \pm 0.00^{b c}$ & $0.16 \pm 0.00^{\text {hi }}$ \\
\hline 12 & $99.25 \pm 0.25^{b}$ & $99.00 \pm 0.00^{c}$ & $0.40 \pm 0.19^{\mathrm{a}}$ & $0.77 \pm 0.01^{a b c}$ & $0.01 \pm 0.00^{c}$ & $0.00 \pm 0.00^{b}$ & $0.03 \pm 0.00^{b c}$ & $0.03 \pm 0.01^{a}$ \\
\hline 13 & $98.50 \pm 0.50^{\mathrm{ab}}$ & $98.00 \pm 0.00^{b c}$ & $0.47 \pm 0.41^{a}$ & $0.91 \pm 0.04^{\mathrm{abc}}$ & $0.02 \pm 0.00^{d}$ & $0.03 \pm 0.00^{n}$ & $0.04 \pm 0.00^{\mathrm{de}}$ & $0.11 \pm 0.00^{f}$ \\
\hline 14 & $99.25 \pm 0.25^{b}$ & $97.50 \pm 0.50^{b}$ & $0.64 \pm 0.25^{\mathrm{a}}$ & $1.78 \pm 0.48^{c}$ & $0.01 \pm 0.00^{c}$ & $0.03 \pm 0.00^{\circ}$ & $0.02 \pm 0.00^{\mathrm{a}}$ & $0.16 \pm 0.01^{h}$ \\
\hline 15 & $99.00 \pm 0.00^{a b}$ & $98.00 \pm 0.00^{b c}$ & $0.75 \pm 0.01^{a}$ & $1.77 \pm 0.01^{\mathrm{c}}$ & $0.01 \pm 0.00^{c}$ & $0.01 \pm 0.00^{i}$ & $0.02 \pm 0.00^{\mathrm{a}}$ & $0.13 \pm 0.01^{\mathrm{g}}$ \\
\hline
\end{tabular}

今े 
Çizelge 3 (devamı). Koyun ve inek Şanlıurfa Sadeyağı örneklerine ait bazı kimyasal özellikler

Table 3 (continue). Some chemical properties of ovine and bovine Şanlıurfa Sadeyağı samples

\begin{tabular}{|c|c|c|c|c|c|c|c|c|}
\hline \multirow[t]{2}{*}{$\begin{array}{l}\text { Örnek } \\
\text { Sample }\end{array}$} & \multicolumn{2}{|c|}{$\begin{array}{c}\text { Serbest asitlik } \\
\text { (mg KOH g } \text { }^{-1} \text { yg) } \\
\text { Free acidity }\left(\mathrm{mg} \mathrm{KOH} \mathrm{g}^{-1} \text { fat }\right)\end{array}$} & \multicolumn{2}{|c|}{ 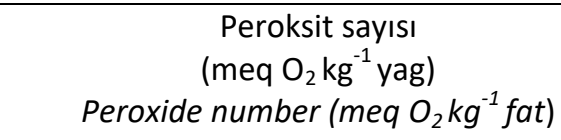 } & \multicolumn{2}{|c|}{$\begin{array}{c}\text { İyot sayısı } \\
\text { lodine number }\end{array}$} & \multicolumn{2}{|c|}{$\begin{array}{c}\text { Sabunlaşma sayısı } \\
\text { (mg KOH g }{ }^{-1} \text { yag) } \\
\text { Saponification number (mg KOH } g^{-1} \text { fat) }\end{array}$} \\
\hline & Koyun & İnek & Koyun & İnek & Koyun & İnek & Koyun & İnek \\
\hline 1 & $0.050 \pm 0.00^{\mathrm{a}}$ & $1.166 \pm 0.01^{\mathrm{d}}$ & $0.159 \pm 0.05^{a b c}$ & $0.079 \pm 0.00^{c}$ & $26.23 \pm 0.88^{\mathrm{ef}}$ & $34.89 \pm 0.68^{\mathrm{gh}}$ & $297.76 \pm 3.05^{\mathrm{ef}}$ & $220.26 \pm 0.08^{d}$ \\
\hline 2 & $0.340 \pm 0.04^{b}$ & $1.274 \pm 0.00^{\mathrm{e}}$ & $0.232 \pm 0.01^{\mathrm{ef}}$ & $0.043 \pm 0.00^{b}$ & $33.36 \pm 1.14^{g}$ & $50.25 \pm 0.58^{j}$ & $296.82 \pm 4.12^{\text {def }}$ & $217.71 \pm 2.16^{\text {cd }}$ \\
\hline 3 & $0.536 \pm 0.01^{d}$ & $8.208 \pm 0.02$ & $0.225 \pm 0.01^{\text {def }}$ & $0.385 \pm 0.00^{g}$ & $18.71 \pm 1.38^{b}$ & $9.45 \pm 0.90^{b}$ & $281.52 \pm 0.04^{b}$ & $206.26 \pm 0.57^{\mathrm{ab}}$ \\
\hline 4 & $0.325 \pm 0.01^{b}$ & $1.518 \pm 0.00^{g}$ & $0.338 \pm 0.00^{h}$ & $0.012 \pm 0.00^{a}$ & $18.20 \pm 0.18^{b}$ & $8.37 \pm 0.25^{b}$ & $287.21 \pm 3.51^{\text {bcde }}$ & $240.25 \pm 2.53^{f}$ \\
\hline 5 & $1.214 \pm 0.00^{g}$ & $2.331 \pm 0.01^{h}$ & $0.196 \pm 0.00^{\text {cde }}$ & $0.012 \pm 0.00^{\mathrm{a}}$ & $19.92 \pm 0.83^{\mathrm{bc}}$ & $25.38 \pm 0.69^{e}$ & $278.89 \pm 0.91^{b}$ & $231.41 \pm 1.02^{e}$ \\
\hline 6 & $1.367 \pm 0.04^{h}$ & $0.997 \pm 0.01^{\mathrm{c}}$ & $0.246 \pm 0.01^{\mathrm{fg}}$ & $0.098 \pm 0.00^{d}$ & $22.33 \pm 0.22^{\text {cd }}$ & $36.60 \pm 0.64^{h}$ & $286.68 \pm 1.33^{\text {bcde }}$ & $246.42 \pm 3.04^{f}$ \\
\hline 7 & $0.288 \pm 0.01^{b}$ & $0.662 \pm 0.01^{b}$ & $0.274 \pm 0.01^{8}$ & $0.029 \pm 0.00^{\mathrm{ab}}$ & $26.86 \pm 1.21^{\dagger}$ & $6.60 \pm 1.21^{b}$ & $286.01 \pm 4.08^{\text {bcde }}$ & $240.97 \pm 3.69^{f}$ \\
\hline 8 & $0.518 \pm 0.01^{d}$ & $1.179 \pm 0.01^{d}$ & $0.122 \pm 0.01^{\mathrm{a}}$ & $0.027 \pm 0.00^{\mathrm{ab}}$ & $23.01 \pm 1.11^{\text {cde }}$ & $2.51 \pm 0.49^{\mathrm{a}}$ & $284.56 \pm 3.26^{\mathrm{bcd}}$ & $244.73 \pm 1.48^{f}$ \\
\hline 9 & $0.319 \pm 0.00^{b}$ & $1.296 \pm 0.04^{\mathrm{ef}}$ & $0.188 \pm 0.01^{\mathrm{bcd}}$ & $0.185 \pm 0.00^{\mathrm{e}}$ & $24.96 \pm 1.53^{\mathrm{def}}$ & $14.02 \pm 2.04^{c}$ & $306.02 \pm 3.64^{f}$ & $211.58 \pm 0.51^{b c}$ \\
\hline 10 & $0.282 \pm 0.01^{b}$ & $2.612 \pm 0.01^{i}$ & $0.188 \pm 0.00^{\text {bcd }}$ & $0.079 \pm 0.00^{c}$ & $27.78 \pm 0.30^{f}$ & $19.79 \pm 1.02^{\mathrm{d}}$ & $295.26 \pm 2.54^{\text {cdef }}$ & $241.02 \pm 0.89^{\dagger}$ \\
\hline 11 & $1.124 \pm 0.02^{\dagger}$ & $3.566 \pm 0.00^{k}$ & $0.227 \pm 0.00^{\mathrm{def}}$ & $0.086 \pm 0.01^{\text {cd }}$ & $25.25 \pm 2.19^{\mathrm{def}}$ & $31.53 \pm 0.16^{\dagger}$ & $294.86 \pm 0.54^{\text {cdef }}$ & $212.28 \pm 2.50^{b c}$ \\
\hline 12 & $0.513 \pm 0.01^{d}$ & $0.520 \pm 0.00^{a}$ & $0.159 \pm 0.00^{\mathrm{abc}}$ & $0.213 \pm 0.02^{f}$ & $43.45 \pm 0.17^{h}$ & $42.48 \pm 1.15^{i}$ & $251.02 \pm 5.92^{\mathrm{a}}$ & $200.63 \pm 2.03^{a}$ \\
\hline 13 & $0.887 \pm 0.03^{e}$ & $2.337 \pm 0.01^{h}$ & $0.148 \pm 0.01^{\mathrm{ab}}$ & $0.223 \pm 0.01^{\dagger}$ & $20.88 \pm 0.24^{\mathrm{bc}}$ & $32.56 \pm 1.07^{\mathrm{fg}}$ & $290.41 \pm 0.90^{\text {bcde }}$ & $215.53 \pm 0.86^{\text {cd }}$ \\
\hline 14 & $1.451 \pm 0.00^{i}$ & $1.328 \pm 0.02^{f}$ & $0.144 \pm 0.01^{\mathrm{ab}}$ & $0.098 \pm 0.00^{d}$ & $25.34 \pm 1.60^{\text {def }}$ & $8.65 \pm 0.08^{b}$ & $285.12 \pm 0.32^{\text {bcde }}$ & $232.57 \pm 3.35^{\mathrm{e}}$ \\
\hline 15 & $0.444 \pm 0.00^{c}$ & $3.146 \pm 0.02^{j}$ & $0.146 \pm 0.00^{\mathrm{ab}}$ & $0.227 \pm 0.00^{f}$ & $10.75 \pm 0.38^{\mathrm{a}}$ & $25.04 \pm 2.02^{\mathrm{e}}$ & $282.73 \pm 9.69^{b c}$ & $229.86 \pm 0.45^{\mathrm{e}}$ \\
\hline
\end{tabular}


Yokuş ve ark., 2019. Harran Tarım ve Gıda Bilimleri Dergisi, 23(4): 463-476
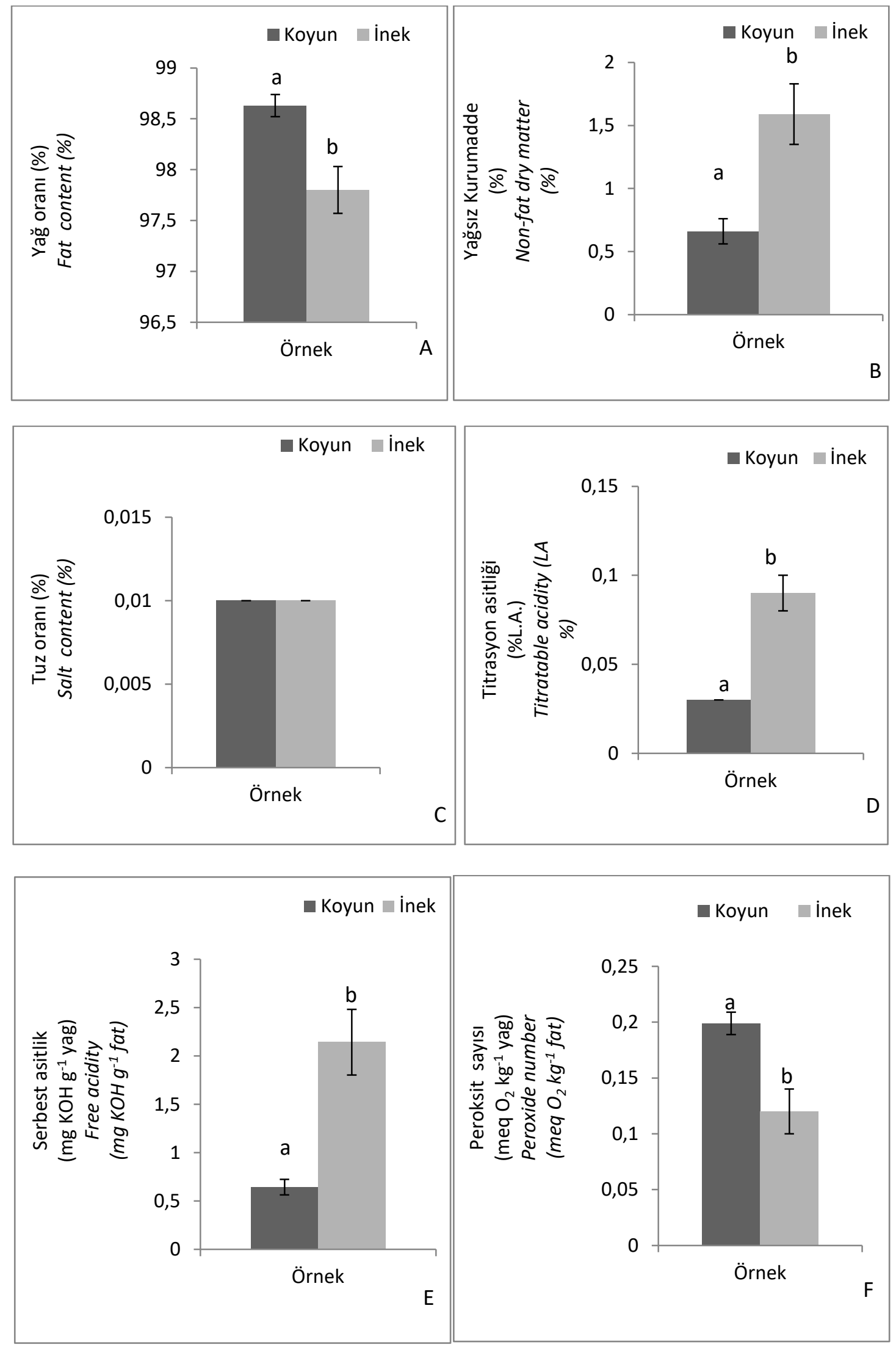


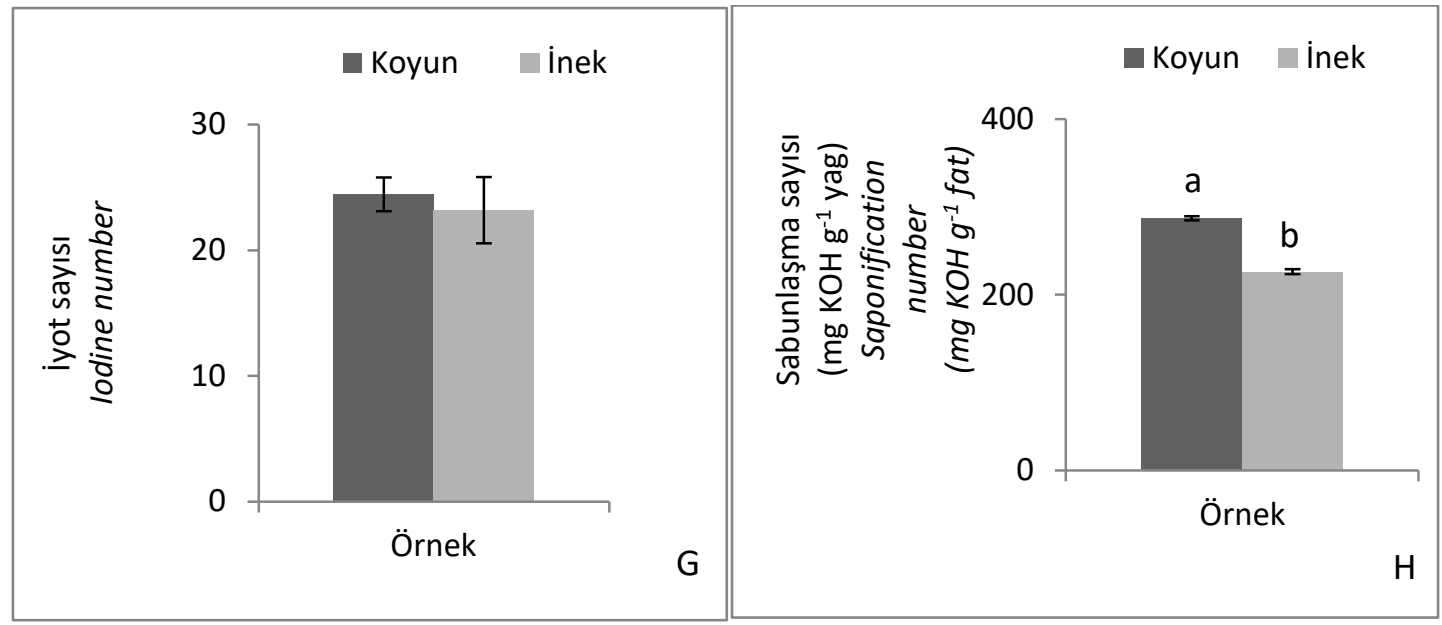

Şekil 2. Koyun ve inek Şanlıurfa Sadeyağlarının kimyasal özelliklerinin ortalama değerleri (A: Yağ oranı; B: Yağsız kurumadde; C: Tuz miktarı; D: Titrasyon asitliği; E: Serbest asitlik; F: Peroksit sayısı; G: İyot sayıSı; H: Sabunlaşma sayısı)

Figure 2. Mean value of chemical properties of ovine and bovine Şanlıurfa Sadeyağı samples (A: Fat content; B: Non-fat dry matter; C: Salt content; D: Titratable acidity; E: Free acidity; F: Peroxide number; G: lodine number; H: Saponification number)

Titrasyon asitliği değeri koyun Şanlıurfa Sadeyağlarında minimum \%0.02, maksimum $\% 0.05$, inek sadeyağlarında ise minimum $\% 0.03$, maksimum \%0.17 arasında olduğu belirlenmiştir. Örneklerin asitlik değerleri arasında fark olduğu tespit edilmiştir $(p<0.05)$. Titrasyon asitliği değerlerinin sadeyağlarda \%0.18-1.79 arasında değiştiği belirtilmektedir (Batun ve ark., 2004; Fındık, 2011). Şanlıurfa Sadeyağlarının titrasyon asitliğinin diğer illerde üretilen sadeyağ örneklerinden çok düşük olması, tereyağının çok kısa sürede sadeyağa işlenmesi, yağ haricindeki kurumadde bileşenlerinin tamamına yakınının hemen uzaklaştırımasından kaynaklandığı tahmin edilmektedir. Titrasyon asitliği değerinin koyun Şanlıurfa Sadeyağlarında inek Şanlıurfa Sadeyağlarından daha düşük olduğu saptanmıştır $(p<0.001)$ (Şekil 2D). Bu sonuca koyun sütünün tampon özelliğinin inek sütünden daha yüksek olmasının sebep olduğu tahmin edilmektedir (Atasoy, 2008). Koyun sütünün inek sütünden daha fazla oranda kazein ve mineral madde içermesi nedeniyle daha düşük asitliğe sahip olduğu belirtilmektedir (Raynal-Ljutovac ve ark., 2007). Tereyağı tip özelliklerine göre titrasyon asitliğinin I. Sınıf yağlarda \%0.27, II. Sınıf tereyağlarında \%0.56, III. Sınıf tereyağlarında \%0.63 olması gerektiği bildirilmektedir (Anonim, 1995). Bu standarda göre Şanlıurfa Sadeyağlarının hepsi birinci sınıf kategorisinde yer almaktadır.

Çizelge 3'te verilen koyun Şanlıurfa Sadeyağlarının serbest asitlik değerleri 0.050$1.451 \mathrm{mg} \mathrm{KOH} \mathrm{g}^{-1}$ yağ, inek sadeyağ örneklerinin ise 0.520-8.208 $\mathrm{mg} \mathrm{KOH} \mathrm{g}^{-1}$ yağ arasında değiştiği saptanmıştır. Tereyağının serbest asit değeri 1.8 $\mathrm{mg} \mathrm{KOH} \mathrm{g}{ }^{-1}$ yağ olması durumunda tat-aroma bozukluğunun algılanabileceği ifade edilmektedir (Atamer, 1993). Koyun Şanlıurfa Sadeyağı örneklerinin serbest asitlik değerleri tamamen bu değerin altında iken, inek sadeyağlarının 6 adedinin bu değerden yüksek olduğu belirlenmiştir. Örneklerin serbest asitlik değerlerinin istatistiksel olarak farklı olduğu saptanmıştır $(p<0.05)$ (Şekil 2E). Bu durumun sütün elde edildiği hayvan ırkı ve türü, tereyağının bileşimi ve üretim yöntemi, sadeyağın depolama koşul, şekil ve süresinin farklı olmasından kaynaklandığı tahmin edilmektedir (Gündoğdu, 2012). Koyun Şanlıurfa Sadeyağının serbest asitlik değerinin, inek sadeyağından çok düşük olduğu tespit edilmiştir $(p<0.001)$ (Şekil 2E). Koyun ve inek sadeyağlarında serbest asitlik değerlerinin sırasıyla 0.423-0.448 $\mathrm{mg} \mathrm{KOH} \mathrm{g}^{-1}$ yağ ve 1.770 -

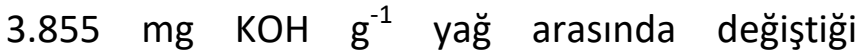
belirtilmektedir (Uruk, 2011). Sawaya ve ark. (1984), Nuami ve Najdi ırkı koyun sütünden elde edilen sadeyağın asitlik değerlerini sırasıyla 1.82 ve $1.91 \mathrm{mg} \mathrm{KOH} \mathrm{g}^{-1}$ yağ olarak saptamışlardır.

Sadeyağlarda oksidasyon düzeyini gösteren testlerden olan peroksit sayısı, bozulmanın başlangıç aşamasında oluşan hidroperoksitlerin düzeyi hakkında fikir vermektedir. Peroksit değeri koyun Şanlıurfa Sadeyağı örneklerinde minimum 0.122 meq $\mathrm{O}_{2} \mathrm{~kg}^{-1}$ yağ, maksimum 0.338 meq $\mathrm{O}_{2}$ $\mathrm{kg}^{-1}$ yağ, inek sadeyağı örneklerinde minimum 0.012 meq $\mathrm{O}_{2} \mathrm{~kg}^{-1}$ yağ, maksimum 0.385 meq $\mathrm{O}_{2}$ $\mathrm{kg}^{-1}$ yağ olduğu belirlenmiştir. Van piyasasında satılan ve tüketilen sadeyağ örneklerinde peroksit değerinin 0.87-12.84 meq $\mathrm{O}_{2} \mathrm{~kg}^{-1}$ yağ aralığında 
olduğu belirtilmektedir (Batun ve ark., 2004; Kirazcı ve Javidipour, 2008; Fındık, 2011). Örneklerin peroksit değerlerinin istatistiksel olarak farklı olduğu belirlenmiştir $(p<0.05)$. Bu durumun Şanlıurfa Sadeyağlarının üretilmesi sırasında uygulanan ısıl işlem sıcaklığının ve süresinin, sadeyağların doymamış yağ asitleri bileşiminin ve asitliğinin, örneklerin depolama sıcaklığının ve süresinin farklı olmasından kaynaklanabileceği tahmin edilmektedir. Koyun Şanlıurfa Sadeyağının ortalama peroksit değerinin inek sadeyağından yüksek olduğu bulunmuştur $(p<0.01)$ (Şekil 2F). Bu sonucun inek ve koyun sütü yağ asitleri kompozisyonunun farklılığından ileri geldiği düşünülmektedir. TS 1331 'e göre tereyağı peroksit sayısı 5 meq $\mathrm{O}_{2} \quad \mathrm{~kg}^{-1}$ yağ olarak belirlenirken sadeyağ için herhangi bir sınırlama getirilmemiştir (Anonim, 2005). WHO/FAO Food Standards (2011), sadeyağ peroksit sayısının 0.6 meq $\mathrm{O}_{2} \mathrm{~kg}^{-1}$ yağ geçmemesi gerektiğini belirtmiştir (Anonim, 2011). Araştırmada tespit edilen peroksit değerleri hem TSE 1331'e hem de WHO/FAO belirtilen peroksit değerlerinden düşük olduğu saptanmıştır.

Doymamışlık derecesinin bir ölçütü olan iyot sayısı sadeyağın bağlayabileceği iyot miktarını göstermektedir. İyot sayılarının koyun Şanlıurfa Sadeyağlarında 10.75-43.45, inek sadeyağlarında ise 2.51-50.25 arasında değiştiği belirlenmiştir. Şanlıurfa Sadeyağlarının iyot değerleri istatistiksel olarak birbirlerinden farklılık göstermektedir $(p<0.05)$. Bu durumun hayvanın tür ve ırkının, sadeyağların üretildiği mevsim ve üretim yönteminin, sadeyağın elde edildiği tereyağın bileşiminin ve depolama şekli ve sürelerinin farklı olmasından kaynaklanabileceği düşünülmektedir. Koyun ve inek Şanlıurfa Sadeyağlarının ortalama değerlerinin istatistiksel olarak aynı olduğu saptanmıştır ( $p>0.05$ ) (Şekil 2G). Uruk (2011), sadeyağ üzerine yaptığı araştırmada koyun ve inek sadeyağlarının iyot sayılarını sırasıyla 28.4-44.6 ve 37.4-45.2 arasında değiştiğini bulmuştur. Sawaya ve ark. (1984)'nın, yapmış oldukları çalışmada Nuami ve Najdi ırkı koyun sadeyağlarının iyot sayısını 31.8 ve 28.4 olarak belirtmişlerdir.

Şanlıurfa Sadeyağı örneklerinin sabunlaşma sayıları Çizelge 3'te gösterilmiştir. Koyun ve inek Şanlıurfa Sadeyağlarına ait sabunlaşma sayıları sırasıyla minimum 251.02 ve $200.63 \mathrm{mg} \mathrm{KOH} \mathrm{g}^{-1}$ yağ, maksimum 306.02 ve $246.42 \mathrm{mg} \mathrm{KOH} \mathrm{g}^{-1}$ yağ olarak saptanmıştır. Örneklerin sabunlaşma sayılarının istatistiksel olarak birbirinden farklı olduğu saptanmıştır $(p<0.05)$. Uruk (2011) da koyun ve inek sadeyağı örneklerinin sabunlaşma sayılarının 199.04-202.95 ve $174.49-222.21 \mathrm{mg}$ $\mathrm{KOH} \mathrm{g}^{-1}$ yağ aralığında değiştiğini belirtmiştir. Koyun sadeyağına ait ortalama sabunlaşma sayısı değeri inek sadeyağından daha yüksek bulunmuştur $(p<0.001)$ (Şekil $2 \mathrm{H})$. Bu sonucun koyun ve inek sütünden üretilen sadeyağların yağ asitleri kompozisyonunun birbirinden farklı olmasından kaynaklandığı tahmin edilmektedir. Koyun sütünün sabunlaşma sayısının inek sütünden daha yüksek olduğu bildirilmektedir (Uraz ve ark., 1983).

\section{Mikrobiyolojik özellikler}

Koyun ve inek Şanlıurfa Sadeyağlarının lipolitik bakteri, maya-küf ve laktik asit bakteri sayıları Çizelge 4 'te toplu olarak verilmiş, sadeyağlara ait ortalama değerler ise Şekil 3'te gösterilmiştir.

Koyun Şanlıurfa Sadeyağlarının lipolitik bakteri sayıları 0.84-3.69 log kob g ${ }^{-1}$, inek sadeyağlarında ise 1.00-4.87 log kob $\mathrm{g}^{-1}$ arasında değiştiği belirlenmiştir. Örneklerin lipolitik bakteri sayılarının istatistiksel olarak birbirinden farklı olduğu saptanmıştır $(p<0.05)$. Fındık (2011), incelemiş olduğu sadeyağ örneklerinin lipolitik bakteri sayısını 1.59-2.55 log kob g $\mathrm{g}^{-1}$ arasında değiştiğini tespit etmiştir. Kirazcı ve Javidipour (2008), ise yaptıkları sadeyağ çalışmasında örneklerin ortalama lipolitik bakteri sayısını 9.9 log kob g ${ }^{-1}$ olarak belirlemişlerdir. İnek ve koyun Şanlıurfa Sadeyağı örneklerinin ortalama lipolitik bakteri sayıları arasında istatistiksel olarak bir fark bulunamamıştır ( $p>0.05$ ) (Şekil 3A).

Koyun Şanlıurfa Sadeyağlarında maya-küf sayısı $<1.00-5.06$ log kob $\mathrm{g}^{-1}$, inek Şanlıurfa Sadeyağlarında ise 1.88-4.74 log kob g $\mathrm{g}^{-1}$ arasında değişmiştir (Şekil 3B). Örneklerin maya-küf sayıları istatistiksel olarak birbirinden farklı bulunmuştur $(p<0.05)$.

Aerobik laktobasillus sayısı koyun Şanlıurfa Sadeyağlarının minimum 0.27 log kob $\mathrm{g}^{-1}$, maksimum 4.74 log kob $\mathrm{g}^{-1}$, inek Şanlıurfa Sadeyağlarının ise minimum $<1$ log kob $\mathrm{g}^{-1}$, maksimum 4.61 log kob g $^{-1}$ olduğu belirlenmiştir. Örneklerin aerobik laktobasillus sayıları istatistiksel olarak farklı olduğu bulunmuştur $(p<0.05)$. Ancak, koyun ve inek Şanlıurfa Sadeyağı örneklerinin ortalama aerobik laktobasillus sayıları arasında istatistiksel açıdan fark bulunamamıştır ( $p>0.05$ ) (Şekil 3C). Fındık (2011) da sadeyağ örneklerinin aerobik laktobasillus sayılarının 5.58-7.01 log kob g ${ }^{-1}$ arasında değiştiğini tespit etmiştir. 
Çizelge 4. Koyun ve inek Şanlıurfa Sadeyağı örneklerine ait bazı mikrobiyolojik özellikler

Table 4. Some microbiological properties of ovine and bovine şanlıurfa Sadeyağı samples

\begin{tabular}{|c|c|c|c|c|c|c|c|c|}
\hline \multirow[t]{2}{*}{$\begin{array}{l}\text { Örnek } \\
\text { Sample }\end{array}$} & \multicolumn{2}{|c|}{$\begin{array}{l}\text { Lipolitik bakteri sayısı }\left(\log \mathrm{kob} \mathrm{g}^{-1}\right) \\
\text { Lipolytic bacteria count }\left(\log c f u \mathrm{~g}^{-1}\right)\end{array}$} & \multicolumn{2}{|c|}{$\begin{array}{l}\text { Maya-Küf sayısı }\left(\log \text { kob g g}^{-1}\right) \\
\text { Yeast-Mold count }\left(\log c f u g^{-1}\right)\end{array}$} & \multicolumn{2}{|c|}{$\begin{array}{l}\text { Aerobik laktobasil sayısı }\left(\log \mathrm{kob} \mathrm{g}^{-1}\right) \\
\text { Aerobic lactobacillus count }\left(\log c f u g^{-1}\right)\end{array}$} & \multicolumn{2}{|c|}{$\begin{array}{l}\text { Aerobik streptokok sayısı }\left(\log \mathrm{kob} \mathrm{g}^{-1}\right) \\
\text { Aerobic streptococcus count }\left(\log c f u g^{-1}\right)\end{array}$} \\
\hline & Koyun & Inek & Koyun & Inek & Koyun & İnek & Koyun & İnek \\
\hline 1 & $2.00 \pm 0.00^{b}$ & $4.07 \pm 0.06^{h}$ & $0.70 \pm 0.00^{d}$ & $4.44 \pm 0.05^{h}$ & $0.71 \pm 0.01^{\mathrm{b}}$ & $3.73 \pm 0.03^{\mathrm{g}}$ & $0.70 \pm 0.00^{\mathrm{a}}$ & $4.16 \pm 0.08^{\mathrm{hi}}$ \\
\hline 2 & $0.84 \pm 0.01^{\mathrm{a}}$ & $4.30 \pm 0.02^{i}$ & $2.51 \pm 0.01^{h}$ & $4.74 \pm 0.06^{i}$ & $1.88 \pm 0.08^{d}$ & $3.98 \pm 0.01^{h}$ & $2.54 \pm 0.10^{\mathrm{e}}$ & $4.43 \pm 0.10^{j}$ \\
\hline 3 & $3.69 \pm 0.07^{h}$ & $1.91 \pm 0.05^{c}$ & $3.50 \pm 0.04^{i}$ & $4.13 \pm 0.00^{f}$ & $4.21 \pm 0.07^{j}$ & $<1 \pm 0.00^{\mathrm{a}}$ & $4.39 \pm 0.03^{h i}$ & $0.88 \pm 0.05^{c}$ \\
\hline 4 & $2.15 \pm 0.07^{b c}$ & $4.87 \pm 0.06^{j}$ & $0.92 \pm 0.00^{\mathrm{e}}$ & $4.42 \pm 0.02^{\text {gh }}$ & $1.64 \pm 0.01^{c}$ & $4.61 \pm 0.02^{j}$ & $2.16 \pm 0.08^{\text {cd }}$ & $4.60 \pm 0.04^{j}$ \\
\hline 5 & $2.89 \pm 0.03^{\mathrm{fg}}$ & $3.01 \pm 0.00^{\mathrm{e}}$ & $<1 \pm 0.00^{a}$ & $4.48 \pm 0.00^{h}$ & $3.41 \pm 0.02^{\mathrm{gh}}$ & $4.53 \pm 0.00^{j}$ & $4.22 \pm 0.09^{h}$ & $4.22 \pm 0.10^{i}$ \\
\hline 6 & $2.28 \pm 0.05^{c d}$ & $3.35 \pm 0.07^{\dagger}$ & $2.36 \pm 0.05^{\mathrm{g}}$ & $4.20 \pm 0.02^{\dagger}$ & $0.27 \pm 0.05^{a}$ & $0.27 \pm 0.05^{b}$ & $1.80 \pm 0.01^{b}$ & $1.85 \pm 0.11^{\mathrm{e}}$ \\
\hline 7 & $2.63 \pm 0.01^{\mathrm{e}}$ & $1.92 \pm 0.00^{c}$ & $1.49 \pm 0.01^{\dagger}$ & $4.14 \pm 0.05^{f}$ & $0.84 \pm 0.02^{b}$ & $<1 \pm 0.00^{\mathrm{a}}$ & $3.03 \pm 0.01^{\dagger}$ & $0.21 \pm 0.01^{b}$ \\
\hline 8 & $2.74 \pm 0.05^{\mathrm{ef}}$ & $1.57 \pm 0.04^{b}$ & $4.13 \pm 0.01$ & $3.53 \pm 0.09^{d}$ & $2.85 \pm 0.01^{\mathrm{e}}$ & $<1 \pm 0.00^{\mathrm{a}}$ & $2.50 \pm 0.13^{\mathrm{e}}$ & $2.58 \pm 0.05^{f}$ \\
\hline 9 & $2.36 \pm 0.17^{d}$ & $3.75 \pm 0.10^{g}$ & $4.16 \pm 0.01$ & $4.27 \pm 0.05^{f g}$ & $3.73 \pm 0.03^{i}$ & $3.73 \pm 0.03^{g}$ & $4.55 \pm 0.08^{i}$ & $4.00 \pm 0.00^{\mathrm{gh}}$ \\
\hline 10 & $2.01 \pm 0.00^{b}$ & $1.57 \pm 0.05^{b}$ & $3.74 \pm 0.08^{k}$ & $3.97 \pm 0.01^{\mathrm{e}}$ & $4.59 \pm 0.04^{k}$ & $2.90 \pm 0.05^{\mathrm{e}}$ & $4.50 \pm 0.00^{i}$ & $1.37 \pm 0.05^{d}$ \\
\hline 11 & $2.11 \pm 0.00^{b c}$ & $3.70 \pm 0.08^{g}$ & $0.53 \pm 0.00^{c}$ & $4.40 \pm 0.04^{\text {gh }}$ & $3.22 \pm 0.04^{f}$ & $4.20 \pm 0.04^{i}$ & $1.94 \pm 0.01^{b c}$ & $4.18 \pm 0.02^{h i}$ \\
\hline 12 & $2.95 \pm 0.02^{\mathrm{g}}$ & $3.61 \pm 0.02^{g}$ & $0.24 \pm 0.01^{b}$ & $1.88 \pm 0.05^{\mathrm{a}}$ & $3.49 \pm 0.03^{h}$ & $0.89 \pm 0.07^{c}$ & $2.19 \pm 0.12^{d}$ & $1.24 \pm 0.02^{d}$ \\
\hline 13 & $3.61 \pm 0.01^{h}$ & $2.29 \pm 0.02^{d}$ & $5.06 \pm 0.00^{\mathrm{m}}$ & $3.24 \pm 0.11^{c}$ & $4.74 \pm 0.06$ & $2.45 \pm 0.09^{d}$ & $5.25 \pm 0.06^{j}$ & $2.60 \pm 0.06^{f}$ \\
\hline 14 & $2.59 \pm 0.06^{\mathrm{e}}$ & $1.00 \pm 0.00^{\mathrm{a}}$ & $3.50 \pm 0.00^{i}$ & $3.60 \pm 0.00^{d}$ & $3.49 \pm 0.07^{h}$ & $3.24 \pm 0.00^{f}$ & $3.63 \pm 0.02^{g}$ & $3.96 \pm 0.03^{g}$ \\
\hline 15 & $2.25 \pm 0.01^{\text {cd }}$ & $1.91 \pm 0.05^{c}$ & $3.60 \pm 0.03^{j}$ & $2.48 \pm 0.06^{b}$ & $3.27 \pm 0.06^{\mathrm{fg}}$ & $<1 \pm 0.00^{\mathrm{a}}$ & $3.54 \pm 0.10^{\mathrm{g}}$ & $<1 \pm 0.00^{\mathrm{a}}$ \\
\hline
\end{tabular}


Yokuş ve ark., 2019. Harran Tarım ve Gıda Bilimleri Dergisi, 23(4): 463-476
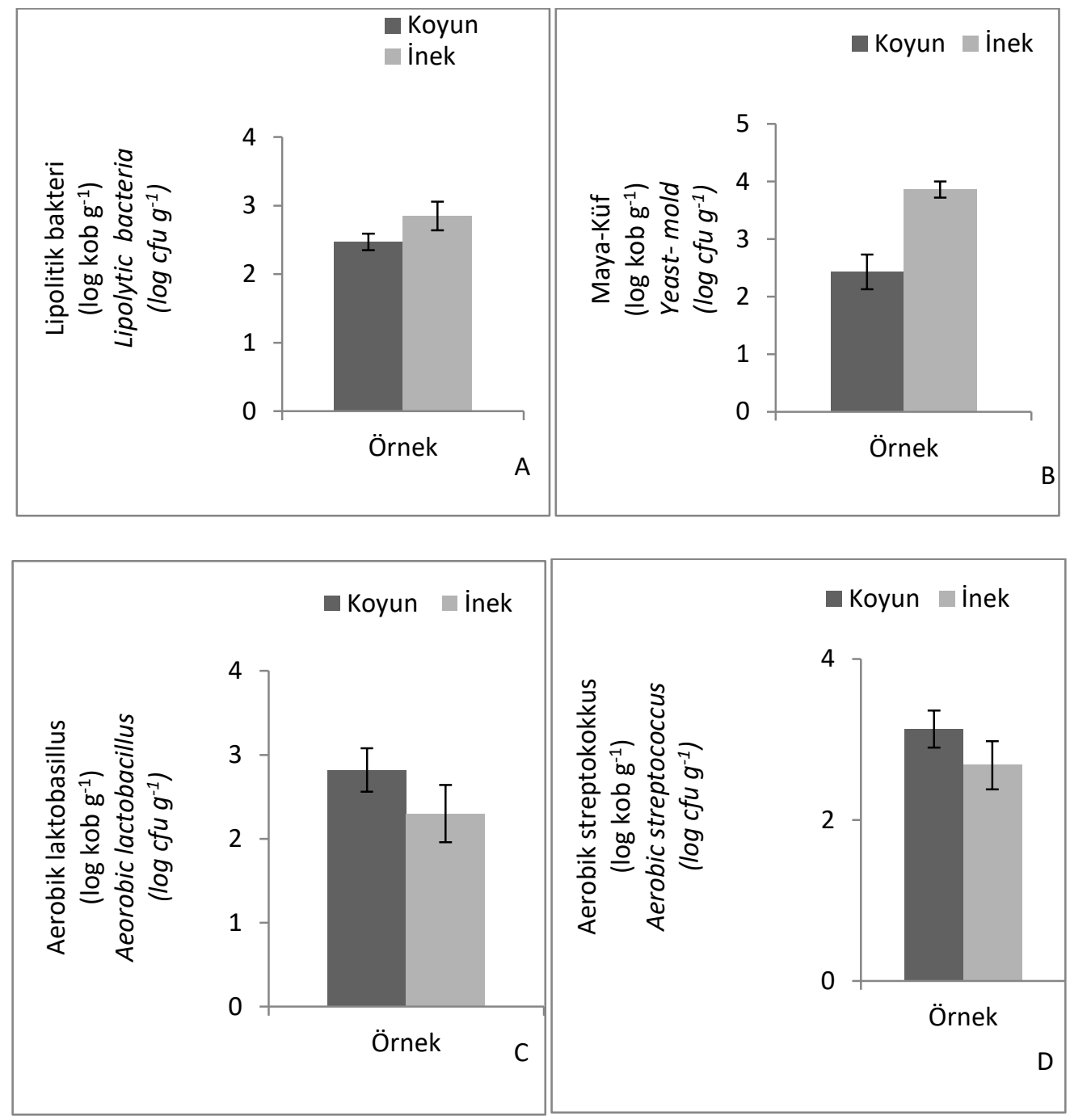

Şekil 3. Koyun ve inek Şanlıurfa Sadeyağlarının mikrobiyolojik özelliklerinin ortalama değerleri (A: Lipolitik bakteri; B: Maya-Küf; C: Aerobik laktobasillus; D: Aerobik streptokokkus)

Figure 3. Mean value of microbiological properties of ovine and bovine Şanlıurfa Sadeyağı (A: Lipolytic bacteria; B: Yeast-mold; C: Aerobic lactobacillus; D: Aerobic streptococcus)

Aerobik streptokokkus bakteri sayısı koyun Şanlıurfa Sadeyağı örneklerinde 0.70-5.25 log kob $\mathrm{g}^{-1}$, inek sadeyağlarının ise $<1.00-4.60 \log _{\text {kob g }}{ }^{-1}$ arasında değiştiği belirlenmiştir. Örneklerin aerobik streptokokkus sayılarının istatistiksel olarak birbirlerinden farklı olduğu görülmüştür $(p<0.05)$. Ancak, koyun ve inek Şanlıurfa Sadeyağı örneklerinin ortalama aerobik streptokokkus sayıları arasında istatistiksel olarak fark saptanmamıştır ( $p>0.05$ ) (şekil 3D). Sadeyağlarda aerobik streptokokkus sayısının 4.00-6.99 log kob $\mathrm{g}^{-1}$ arasında değiştiği bildirilmektedir (Fındık, 2011).

Koyun ve inek Şanlıurfa Sadeyağlarının mikrobiyolojik özellikleri arasında fark bulunmamasına rağmen, sadeyağ örneklerinin mikrobiyolojik özelliklerinin çok geniş bir aralığa sahip olduğu belirlenmiştir. Bu durumun Şanlıurfa Sadeyağı üretiminde standart bir yönteminin olmaması, gerek üretim gerekse depolama sırasında hijyen kurallarına dikkat edilmemesi ve depolama koşullarının uygun olmamasından kaynaklandığı düşünülmektedir.

\section{indüksiyon Periyodu}

Indüksiyon periyodu, belirli sıcaklık ve hava akışında yağların oksidasyonu sonucu oluşan uçucu bileşenlerin artışına paralel, belirli bir kırılma noktasının belirlendiği bir değerdir. İndüksiyon periyodu, parçalanma ürünlerinin damıtık suya transfer olması sonucu suyun iletkenliğinde oluşan değişimle ölçülür. İndüksiyon periyodu ne kadar uzun ise yağın oksidatif stabilitesi o kadar yüksektir (Kıralan, 2006). Koyun ve inek sadeyağı örneklerine ait indüksiyon periyodu değerleri Çizelge 5 'te, sadeyağlara ait ortalama değerler ise Şekil 4'te gösterilmiştir. 
Çizelge 5. Koyun ve inek Şanlıurfa Sadeyağı örneklerine ait indüksiyon periyodu değerleri

Table 5. Induction period values of ovine and bovine Şanlıurfa Sadeyağı samples

\begin{tabular}{|c|c|c|}
\hline \multirow[t]{2}{*}{$\begin{array}{l}\text { Örnek } \\
\text { Sample }\end{array}$} & \multicolumn{2}{|c|}{$\begin{array}{l}\text { İndüksiyon periyodu (sa) } \\
\text { Induction period (h) }\end{array}$} \\
\hline & Koyun & İnek \\
\hline 1 & $2.38 \pm 0.01^{\mathrm{g}}$ & $4.42 \pm 0.02^{d}$ \\
\hline 2 & $2.13 \pm 0.02^{f}$ & $11.39 \pm 0.01^{i}$ \\
\hline 3 & $13.53 \pm 0.05^{\top}$ & $0.05 \pm 0.00^{\mathrm{a}}$ \\
\hline 4 & $0.91 \pm 0.01^{\mathrm{c}}$ & $6.61 \pm 0.01^{\mathrm{g}}$ \\
\hline 5 & $0.23 \pm 0.01^{a}$ & $11.20 \pm 0.01^{i}$ \\
\hline 6 & $0.7 \pm 0.01^{b}$ & $5.35 \pm 0.25^{\mathrm{e}}$ \\
\hline 7 & $2.45 \pm 0.00^{\mathrm{g}}$ & $12.20 \pm 0.00^{j}$ \\
\hline 8 & $6.41 \pm 0.05^{j}$ & $5.77 \pm 0.02^{f}$ \\
\hline 9 & $1.18 \pm 0.04^{d}$ & $14.15 \pm 0.01^{k}$ \\
\hline 10 & $5.07 \pm 0.03^{i}$ & $3.39 \pm 0.11^{c}$ \\
\hline 11 & $1.56 \pm 0.01^{\mathrm{e}}$ & $2.90 \pm 0.03^{b}$ \\
\hline 12 & $13.64 \pm 0.01^{\mathrm{m}}$ & $9.94 \pm 0.08^{h}$ \\
\hline 13 & $11.47 \pm 0.08^{k}$ & $0.10 \pm 0.02^{\mathrm{a}}$ \\
\hline 14 & $3.75 \pm 0.01^{h}$ & $0.08 \pm 0.00^{\mathrm{a}}$ \\
\hline 15 & $2.44 \pm 0.03^{g}$ & $0.05 \pm 0.00^{a}$ \\
\hline
\end{tabular}

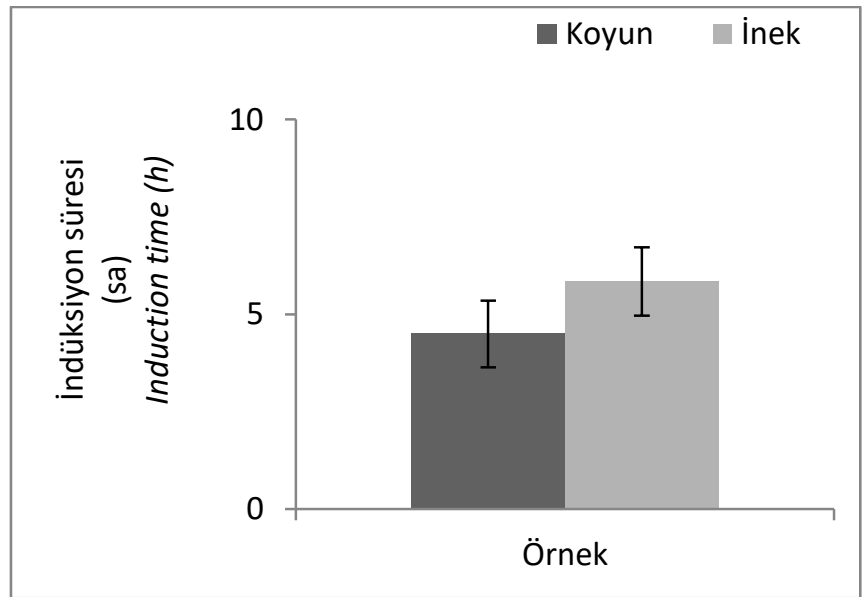

Şekil 4. Koyun ve inek Şanlıurfa Sadeyağlarının ortalama indüksiyon periyodu değerleri (saat)

Figure 4. Mean value of induction period of ovine and bovine Şanlıurfa Sadeyağı (hour)

Koyun ve inek Şanlıurfa Sadeyağlarına ait indüksiyon periyodu değerleri sırasıyla minimum 0.23 ve 0.05 saat, maksimum 13.64 ve 14.15 saat, ortalama 4.52 ve 5.84 saat aralığında değiştiği saptanmıştır. Örneklerin indüksiyon periyodu değerleri arasında fark istatistiksel olarak önemli bulunmuştur $(p<0.05)$. Bu durumun sadeyağ örneklerinin yağ asitleri bileşiminin ve allil (-C=C-) grubu sayısının, depolama sıcaklığı ve sürelerinin, ambalaj malzemelerinin farklı olmasından kaynaklandığı düşünülmektedir. Yağ asitlerinin allil grubu arttıkça oksidatif tepkimenin indüksiyon periyodunun kısaldığı ve reaksiyon hızının arttığı belirtilmektedir (Belitz ve Grosch, 1992).

\section{Sonuç}

Koyun ve inek Şanlıurfa Sadeyağı örneklerinin kırılma indisi, kurumadde miktarı, tuz miktarı, iyot sayısı, lipolitik bakteri sayısı, laktik asit bakteri sayısı ve indüksiyon periyodu değerlerinin benzer olmasına karşın diğer kalite özelliklerinin birbirinden farklı olduğu belirlenmiştir. Ayrıca, Şanlıurfa Sadeyağı örneklerinin fiziksel, kimyasal, mikrobiyolojik kalite özellikleri ile indüksiyon periyotları arasında önemli farklılıkların olduğu bulunmuştur. Bu değerlerin farklılık göstermesinin nedenleri arasında; hammaddenin farklı özellikte ve kalitede olması, standart bir üretim metodunun olmaması ve depolama süre ve sıcaklığının değişken olması ve ambalaj malzemelerin farklılığı sayılabilir. Şanlıurfa Sadeyağının standart bir üretim metodunun ve kalite kriterlerinin oluşturulmadığı belirlenmiştir. Bu nedenle, Şanlıurfa Sadeyağının süt türüne göre fiziksel, kimyasal ve mikrobiyolojik özelliklerinin belirlenmesi, standart bir üretim metodunun oluşturulması ve kalite kriterlerinin belirlenmesi için araştırmalar yapılması gerekmektedir.

\section{Ekler}

Bu çalışma, Harran Üniversitesi Bilimsel Araştırma Projeleri Koordinatörlüğü (HÜBAP) tarafından desteklenmiştir (Proje No: 16024).

\section{Kaynaklar}

Anonim, (1995). TS 1331 Tereyağı Standardı. Türk Standartları Enstitüsü, Ankara.

Anonim, (2005). Tereyağı, diğer süt yağı esaslı sürülebilir ürünler ve sadeyağ tebliği, Türk Gıda Kodeksi, Tebliğ No: 2005/19, Ankara.

Anonim, (2011). WHO/FAO Food Standards, CODEX STAN 280-1973 
www.codexalimentarius.net/download/standards/1 71/CXS_280e.pdf. Erişim tarihi: 28.02.2019.

AOAC, (1990). Official methods of analysis of the AOAC, 15th ed. Methods 932.06, 925.09, 985.29, 923.03. Association of official analytical chemists. Arlington, VA, USA.

Atamer, M. (1993). Tereyağı Teknolojisi Uygulama Kılavuzu, Ankara Üniversitesi Ziraat Fakültesi Yayınları, Ankara, 16-27s.

Atasoy, A. F. (2008). Evaluation of pH change kinetics during different stages of kashar cheese production from bovine, ovine and caprine milk, Journal of Food Processing and Preservation, 32(3), 416 - 428. https://doi.org/10.1111/j.1745-4549.2008.00187.x

Atasoy, A.F., ve Türkoğlu H. (2010). Şanlıurfa'da üretilen ve satışa sunulan sadeyağların (Urfa Yağı) serbest yağ asitleri bileşiminin belirlenmesi üzerine bir araştırma, Harran Üniversitesi Ziraat Fakültesi Dergisi, 14(2), 912. Retrieved from http://dergipark.org.tr/harranziraat/issue/18431/19 4157

Batun, P., Kirazcı A., Küçük, M., Çoksöyler, N., ve Javidipour, i. (2004). Van ve çevresinde imal edilen yemeklik sadeyağların kimyasal ve mikrobiyolojik özellikleri. Geleneksel Gıdalar Sempozyumu Bildiriler Kitabı, 2324 Eylül, 201-205s. Van.

Belitz, H. D.,ve Grosch W. (1992). Handbuch der lebensmittelchemie. 4. Auflage. Berlin, Heidelberg, New York, Springer Verlag.

BS 684, (1987). British Standard Institution, London.

Egan, H., Kirk, R.S., ve Sawyer, R. (1981). Pearson's Chemical Analysis of Foods Longman Inc, New York .

Frank, J.F., ve Yousef, A.E. (2004). Tests for groups of microorganisms, in standarts method for the examination of dairy products, American Public Health Association, Washington DC, USA, 227-248.

Fındık, O. (2011). Van'da piyasaya sunulan bazı tereyağı İle bu tereyağlarından elde edilen sadeyağların bazı kimyasal ve mikrobiyolojik özelliklerinin karşılaştırılması. (Yüksek lisans tezi). Retrieved from https://www.ulusaltezmerkezi.net/vanda-piyasayasunulan-bazi-tereyaglari-ile-bu-tereyaglardan-eldeedilen-sadeyaglarin-bazi-kimyasal-ve-mikrobiyolojikozelliklerinin-karsilastirilmasi/

Gündoğdu, E. (2012). Yoğurt ve kremadan üretilen tereyağlarının aroma profili ve bazı kalite özellikleri üzerine kültür kullanımının ve muhafaza süresinin etkileri. (Doktora tezi). Retrieved from http://kutuphane.atauni.edu.tr/yordambt/yordam.p $\mathrm{hp}$ ?-ac=arama\&bolum $=01$

Halkman, A.K. (2005). Gıda Mikrobiyolojisi Uygulamaları. Başak Matbaası, Ankara, 243s.

Kıralan, M. (2006). Ayçiçek yağının oksidatif stabilitesi üzerine Isırgan (Urtica diocia L.) Keten (Linum usitassium L.), Kişniş (Coriandrum sativum L.) ve Çörekotu (Nigella sativa L.) tohum ekstraktlarının etkileri. (Yüksek lisans tezi). Retrieved from https://scholar.google.com.tr/scholar?hl=tr\&as_sdt= 0\%2C5\&q=AY\%C3\%87\%C4\%B0\%C3\%87EK+YA\%C4\%9 EININ+OKS\%C4\%BODAT\%C4\%BOF+STAB\%C4\%BOL\%C 4\%B0TES\%C4\%B0+\%C3\%9CZER\%C4\%BONE+ISIRGAN +\%28Urtica+diocia+L.\%29\%2C+KETEN+\%28Linum+us itassium+L.\%29\%2C+K\%C4\%B0\%C5\%9EN\%C4\%B0\%C $5 \% 9 E+\% 28$ Coriandrum+sativum+L.\%29+VE+\%C3\%87 \%C3\%96REKOTU+\%28Nigella+sativa+L.\%29+TOHUM +EKSTRAKTLARININ+ETK\%C4\%BOLER\%C4\%B0+\&btnG $=$

Kirazcı, A., ve Javidipour, I. (2008). Some chemical and microbiological properties of ghee produced in Eastern Anatolia. International Journal of Dairy Technology, $61 \quad$ (3), 300-306. https://doi.org/10.1111/j.1471-0307.2008.00402.x

Raynal-Ljutovac, K., Park, Y.V., Gaucheron, F., ve Bouhallab, S. (2007). Heat stability and enzymatic modifications of goat and sheep milk. Small Ruminant, 68(1), 207220.

https://doi.org/10.1016/j.smallrumres.2006.09.006

Sawaya, W. N., Khan, P., ve Al-Shalfat, A.F. (1984). Physical and chemical characteristics of ghee and butter from goat's and sheep's milk. Food Chemistry, 14(3), 227232. https://doi.org/10.1016/0308-8146(84)90061-X

Tahmas Kahyaoğlu, D., ve Çakmakçı, S. (2018). A comparative study on some properties oxidation stability during storage of butter produced from different animals' milk. Gida, 43(2), 283-293. https://doi.org/10.15237/gida.GD17081

Uraz, T., Sezgin, E., Koçak, C., ve Yetişemeyen, A. (1983). Süt ve Süt Mamulleri Teknolojisi, Segem Yayınları, Yayın No: 103, Ankara, 89-100.

Uruk, H.A. (2011). Farklı hayvan sütlerinden üretilen tereyağlarının lipit kısmında bazı bileşen farklılıklarının belirlenmesi. (Yüksek lisans tezi). Retrieved from http://openaccess.inonu.edu.tr:8080/xmlui/bitstrea m/handle/11616/6205/Tez\%20Dosyas\%C4\%B1.pdf?s equence $=1 \&$ isAllowed $=y$ 